\title{
Transport mobility of Russian super-large cities
}

\author{
Ramil Zagidullin*1, and Rumiya Mukhametshina ${ }^{1[0000-0002-1215-263 x]}$ \\ ${ }^{1}$ Kazan State University of Architecture and Engineering, 420043 Kazan, Russia
}

\begin{abstract}
The relevance of the issue under study stems from the lack of a method and indicators for determining the population's level of transport mobility. The purpose of the article is to develop a method for assessing the level of transport mobility. The analysis of studies on the quality of transport services has shown lack of attention to mobility as a public transport service for the public. There are currently no science-based criteria for assessing the mobility level of convenience for passengers who use various modes of public transport for their trips. The use of a transport mobility index will improve both the quality of passenger transport and the overall level of transport services. The developed method for assessing the level of transport mobility will allow researchers to look into the dynamics of the indicators and plan improvements to transport service quality. The presence of a welldeveloped metro network (more than one line) in cities provides a transport mobility index above 0.5 , according to the study of Russia's largest cities' transport mobility index. Following the example of Rostov-on-Don, which has the smallest area of the cities under study, a high transport mobility index of 0.6 can be achieved through optimal organization of public transport within the city and without a metro network. The existence of lengthy dedicated public transport lanes does not guarantee a high index of urban mobility, as in Kazan. This is due to a predominance of bus lanes being introduced in the central part of the city: this does not allow the outlying areas and the city as a whole to be given a high level of transport mobility.
\end{abstract}

Keywords. Transport planning, transport mobility index, public transport, metro, shuttle buses, bus lane.

\section{Introduction}

Historically, towns grew up at the crossroads of trade routes and eventually became major transport hubs. Cities have retained their importance as transport hubs in today's world, but with the advancement of engineering and technology in various fields of the national economy and population growth, cities have developed their own internal urban transport system featured by a one-of-a-kind street and road network (SRN) structure. Each city has connections to other cities, and the larger the city, the more passenger and freight interactions it has. The concern emerges from connecting external roads to the urban SRN.

Only some part of the traffic entering the city from the offsite roads has a destination within the city limits. The rest of the traffic is in transit as it passes through the city.

${ }^{*}$ Corresponding author: r.r.zagidullin@mail.ru 
The challenge is that local and transit traffic must be separated, and offsite traffic flows must be connected to the urban SRN safely and efficiently.

The principal diagrams for linking offsite roads to the urban SRN are shown in Fig. 1, depending on the availability of transit traffic:

- excluded;

- partial;

- maximum.

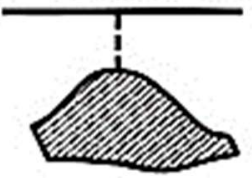

a) transit excluded

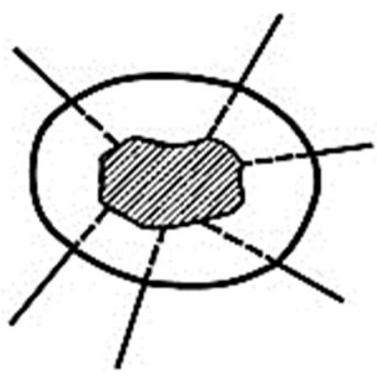

b) partial transit

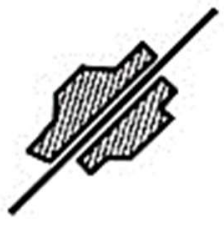

c) maximum transit

Fig. 1. Diagrams of offsite roads connections with urban SRN (illustration by the authors).

The economic justification for roundabouts and bypasses can be determined by calculating the total transport effect, which is based on the reduction of total costs associated with driving time and excessive mileage of vehicles.

The route for transit traffic through the city (Fig. 1b) in its diameter direction is shorter than that of a bypass road. However, the travel time for such traffic will be much longer due to delays at intersections, resulting in low traffic speeds on the urban SRN. The feasibility of a bypass arises when there is a noticeable difference in traffic speeds (1.5-2 times) between the bypass and the urban SRN.

This condition is almost always met in large cities, where the average speed is 25-30 $\mathrm{km} / \mathrm{h}$, whereas on a bypass road the average speed is at least $60 \mathrm{~km} / \mathrm{h}$ if the intersections are multi-level. It is at least $50 \mathrm{~km} / \mathrm{h}$ for roundabouts or regulated intersections. Furthermore, bypass roads can be used to build transport links between the city's outskirts, making these roads more economically viable.

The operation and development of urban transport systems are only possible if the primary issues of road transport are resolved and the adverse effects on the society resulting from the road traffic are minimized. The main issues that road transport may pose are:

1. Environmental pollution.

2. Roads have a high accident rate.

3. Ineffective urban planning policies for the comprehensive development of areas and the formation of a transport-planning framework [1-6].

Transport networks in most cities around the world remain underdeveloped and out of step with demand growth. The demand for movement arises not for the sake of movement itself, but to meet specific needs (work, leisure, health) and to carry out various types of activities in specific locations.

Continuous maintenance of the city transport infrastructure in a usable state, as well as justification of investments in expanding and improving it, necessitate that the management decision-making process is structured with due regard for all available information on passenger and freight transport traffic, as well as potential trends in the further growth of transport processes. The task of transport planning involves the generation of relevant data arrays, their detailed, science-based processing, and, successful decisions on transport infrastructure growth based on this. 
Since there is no systemic approach to urban agglomeration transport planning, various modes of transport are only viewed in isolation. Many important interrelationships between elements of the transport infrastructure may be overlooked by decision-makers in the future due to such a planning approach, resulting in incorrect conclusions.

Research in transport planning and the development of transport systems has been the subject of scientific papers by E.M. Lobanov, V.V. Cherepanov, V.V. Silyanov [7], A.E. Gorev, V.V. Zyryanov [8], M.Ya. Blinkin, M.R. Yakimov [9-13].

In present-day society, ensuring mobility has become a necessity. Mobility, in its broadest sense, refers to the capacity of communicating spatially, mentally, socially, and professionally. Transport mobility is the ability to transfer people in space. Increased mobility, on the other hand, is still at odds with the capacity of relevant infrastructures.

Cities with a mixed-mode transport system give all people, not just car owners, access to mobility. In such cities, all citizens have access to alternative modes of transport, including those that are not dependent on traffic congestion on the streets and roads. Finally, mobility (which is typically very high in car-oriented cities) is much less important than accessibility, i.e., the ability to move between various locations where everyday activities of people take place [14-17].

Most people seek their privacy, but this aspiration should not be absolutized. Total privacy means no contact with others. Humans, on the other hand, are social creatures who choose to live in cities where they can communicate with other people. Public life is much more constrained in agglomerations geared toward a near-total predominance of car commuting than in cities where different modes of transport coexist. As a matter of fact, the use of a mixed landuse model, humanitarian-oriented planning solutions for residential and business growth, and the arrangement of pedestrian zones, all encourage the activation of public life [18].

Increasing mobility when buying cars leads to a dead end because, even in the absence of financial constraints, it is difficult to build an adequate transport network due to a shortage of accessible spaces and the environmental implications. The main global environmental effect of extensive car use has been the warming of our planet's climate, along with industrial and agricultural activities.

In this context, the transport policy of the cities and towns in the world that have passed motorization levels of more than 300 cars per 1000 residents has set out to develop public transport with a high level of service while discouraging the use of private (individual) transport.

The development of public transport is closely related to the need of reducing the costs of society to maintain the population required level of mobility. The need for additional resources cannot be met by unlimited increase in costs while improving the quality of life. As a result, efforts must be made to lower resource consumption costs, particularly in the transport and energy sectors.

Let us consider a study of transport systems in Russian cities.

The renowned consultancy Arthur D. Little has published a report on the mobility of modern cities and future projections. The document evaluated the ease of movement in 84 of the world's largest cities based on 19 different criteria. The top ten most mobile cities are Hong Kong (58.2), Stockholm (57.4), Amsterdam (57.2), Copenhagen (56.4), Vienna (56), Singapore (55.6), Paris (55.4), Zurich (55), London (53.2) and Helsinki (53.1). Moscow and Toronto each scored 44 and St. Petersburg - 43.4. The mobility levels and targets of mobility development in 2011 were determined by analyzing the situation in 66 cities around the world and assigning mobility indices to them. In 2013, the list was expanded to 84 cities, which were evaluated using a 100score scale and 19 criteria, 11 of which reflect the level of development of the city transport system in terms of consistency of different public transport modes, traffic unit trip intervals, and consumer qualities, also including average trip time. Besides, the evaluation took into account pollution and the cities pursuit of more efficient transport networks.

On July 19, 2018, McKinsey \& Company, an international management consultancy, launched its report «transport Systems in 24 Global Cities: The Ingredients for Success». The purpose of the three-month study was to provide a comprehensive assessment of urban transport systems in terms of both objective indicators and residents perceptions. McKinsey 
experts compared 24 cities globally across five dimensions that affect the quality of life: accessibility of infrastructure, affordability, efficiency, convenience, and safety of various modes of transport. The study identified 10 metropolitan cities with the most developed transport systems: Singapore (64.1\%), Paris (62.1\%), Hong Kong (60.0\%), London $(58.0 \%)$, Madrid (57.2\%), Moscow (56.1), Chicago (55.6\%), Seoul (54.7\%), New York (54.6\%), and Milan (54.1\%). Moscow ranked sixth in the overall transport ranking, with Singapore, Greater Paris, and Hong Kong in the top three. Next are London, Madrid, Chicago, Seoul, New York, and Milan (with the province of the same name). At the same time, Moscow ranked fourth in the public transport ranking, while the Russian capital did not make it into the top ten in the ranking of individual transport systems. The leaders here were Madrid, Toronto, and Singapore. Moscow (68.1\%) came in second place in the transport efficiency ranking, with Russia beating the leader, Singapore (65.2). Seoul came first (68.7\%). The leaders in transport safety were Paris, Hong Kong, and Singapore.

SIMETRA analyzed the performance of transport systems in 60 major Russian cities and ranked the quality of public transport. Because of their major differences from other cities, Moscow and St. Petersburg were excluded from the study. The company experts analyzed five groups of parameters: physical and cost accessibility for the public, transport network efficiency, ride comfort, and safety. Yekaterinburg (73.5) topped the Top-10 rating, followed by Izhevsk (70.6), Samara (69.3), Kazan (68.8), Volgograd (65.1), Novgorod (64.9), Novosibirsk (64.0), and Perm (63.4). Novgorod (64.9), Novosibirsk (64.0), Kirov (64.0), Perm (63.4), with Chelyabinsk coming $11^{\text {th }}(62.3)$, Osmk (59.6) 16th, Rostov-on-Don 21st (57.6), Krasnoyarsk 25th (56.6), Ufa 32nd (55.5), and Voronezh 58th (46.9) [19].

In terms of length of bus lanes (BL), Russian cities were ranked according to 2019 data as shown below (Table 1).

Table 1. Length of bus lanes of Russian cities.

\begin{tabular}{|c|c|c|c|}
\hline $\begin{array}{l}\text { Seq. } \\
\text { No. }\end{array}$ & City & BL length (km) & $\begin{array}{c}\text { Relative BL length per } 1000 \text { inhabitants, } \\
\text { (m/1000 persons) }\end{array}$ \\
\hline 1 & Kazan & 182.4 & 146.7 \\
\hline 2 & Naberezhnye Chelny & 49.0 & 92.0 \\
\hline 3 & Moscow & 667.3 & 53.4 \\
\hline 4 & Krasnoyarsk & 51.4 & 47.1 \\
\hline 5 & Rostov-on-Don & 29.5 & 26.1 \\
\hline 6 & Krasnodar & 22.1 & 24.6 \\
\hline 7 & Tyumen & 16.3 & 21.2 \\
\hline 8 & Cherepovets & 6.1 & 19.0 \\
\hline 9 & Khimki & 4.7 & 18.7 \\
\hline 10 & Orenburg & 9.9 & 17.5 \\
\hline 11 & Cheboksary & 8.6 & 17.4 \\
\hline 12 & Veliky Novgorod & 3.5 & 15.5 \\
\hline 13 & Ufa & 16.6 & 14.8 \\
\hline 14 & Volgograd & 13.1 & 12.9 \\
\hline 15 & Izhevsk & 8.2 & 12.6 \\
\hline 20 & Perm & 11.6 & 11.0 \\
\hline 23 & Saint-Petersburg & 51.2 & 9.6 \\
\hline 25 & Samara & 9.5 & 8.2 \\
\hline 27 & Novosibirsk & 11.2 & 7.0 \\
\hline 28 & Ekaterinburg & 9.8 & 6.6 \\
\hline 31 & Omsk & 3.9 & 3.3 \\
\hline 36 & Nizhny Novgorod & 2.6 & 2.1 \\
\hline 38 & Chelyabinsk & 2.1 & 1.7 \\
\hline
\end{tabular}

Table 2 shows a list of metro systems and high-speed electric transport in Russian cities. 
Table 2. Underground and high-speed tramway lengths in Russian cities.

\begin{tabular}{|c|l|c|c|c|}
\hline $\begin{array}{c}\text { Seq. } \\
\text { No. }\end{array}$ & \multicolumn{1}{|c|}{ Metro system } & Network length (km) & Lines & Stations \\
\hline 1 & $\begin{array}{l}\text { Moscow (with MCC and overhead } \\
\text { monorail conveyors) }\end{array}$ & $408.1(466.8)$ & $15(17)$ & $238(275)$ \\
\hline 2 & St. Petersburg & 124.8 & 5 & 72 \\
\hline 3 & Nizhny Novgorod & 21.82 & 2 & 15 \\
\hline 4 & Volgograd (high-speed tram) & 17.3 & 1 & 22 \\
\hline 5 & Kazan & 16.77 & 1 & 11 \\
\hline 6 & Novosibirsk & 15.9 & 2 & 13 \\
\hline 7 & Yekaterinburg & 12.7 & 1 & 9 \\
\hline 8 & Samara & 12.6 & 1 & 10 \\
\hline
\end{tabular}

The issues of passenger transport organization and safe traffic are addressed in some scientific works by V.V. Silyanov [20], A.E. Gorev, V.A. Gudkov, V.V. Zyryanov, V.A. Korchagin, L.B. Mirotin, A.N. Novikov [21], I.V. Spirin, S.A. Shiryaev, N.N. Yakunin [22], N.V. Yakunina [23] et al.

As the role of urban passenger transport in achieving efficient mobility changes, so does the assessment of its performance. Whereas the key criterion for assessing it until now were such indicators as total mileage, amount of work performed, etc., parameters related to meeting the population need for transport services, such as travel speed, average daily commuting time, etc., must now be applied for evaluation. With this in mind, the role of marketing as a key tool for the design of integrated transport systems is rising in importance. In such systems, different modes of transport are used in an integrated manner to provide the population with the most efficient mobility. For example, many major airports have established express off-street transport systems to take passengers to central city locations, thus reducing overall passenger trip time.

To investigate the level of transport mobility, Table 3 provides a classification according to the population size of the cities. A further study focuses on the category of super-large and major Russian cities with populations exceeding one million people.

Table 3. Urban classification by population size.

\begin{tabular}{|l|c|}
\hline \multicolumn{1}{|c|}{ Class } & Population, thousand inhabitants \\
\hline Giant & over 5000 \\
\hline Super large & 1000 to 5000 \\
\hline Large & 500 to 1000 \\
\hline Big & 250 to 500 \\
\hline Medium & 100 to 250 \\
\hline Towns & 50 to 100 \\
\hline Villages & 10 to 50 \\
\hline Settlements & up to 10 \\
\hline
\end{tabular}

Let us calculate the estimated transport mobility of Russian largest cities, to which urban settlements with a population of more than 1 million people belong, according to the method developed.

\section{Methods}

The Index of Transport Mobility (ITM) is the ratio of the average commuting time by private car $\left(\bar{t}_{i}\right)$ to the average commuting time by public transport $\left(\bar{t}_{p}\right)$ :

$$
M_{\mathrm{T}}=\frac{\bar{t}_{\text {至}}}{\bar{t}_{\mathrm{o}}}
$$


The routes for determining the city index of transport mobility are the way from the city center to the city limits (the nearest public transport stop to the city limits) along the main radial traffic routes in the city (Fig. 2).

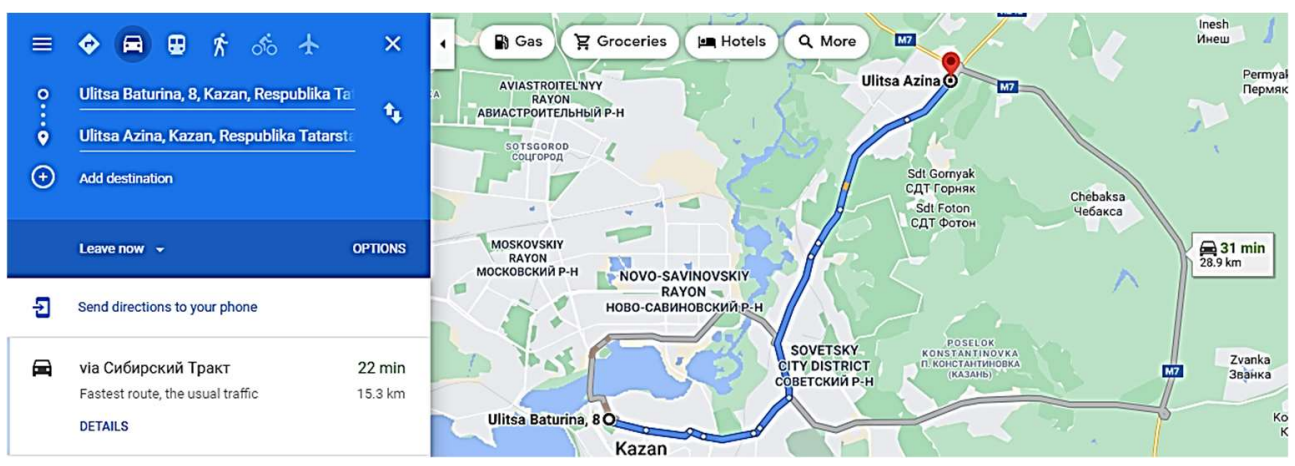

Fig. 2. The route for determining the index of transport mobility in Kazan (illustration made by the authors).

For road and urban public transport, it is recommended to calculate travel times based on public mapping services (e.g., Yandex and Google) that provide information on the actual traffic situation rather than at peak times during the day, when public transport is operating normally.

It is suggested that the level of transport mobility (LTM) is to be assessed based on the following values of the index of transport mobility (Table 4).

Table 4. Levels of transport mobility.

\begin{tabular}{|c|c|}
\hline Level of transport mobility (LTM) & Index of transport mobility (ITM) \\
\hline A & more than 1.0 \\
\hline B & $0.81-1.0$ \\
\hline C & $0.61-0.8$ \\
\hline D & $0.41-0.6$ \\
\hline E & $0.21-0.4$ \\
\hline F & less than 0.2 \\
\hline
\end{tabular}

The index of transport mobility can also be defined for other traffic parameters such as trip speed, cost, etc. as an additional criterion.

\section{Results and discussions}

Let us calculate the index of transport mobility of Russian largest cities (Table 5).

As a result of the index of transport mobility calculation according to Table 5, the level of transport mobility of the cities was assigned and the rating of the cities was made.

Moscow has the highest index of transport mobility ( 0.81$)$, which is also supported by the studies of the world cities discussed above. The second and third places are shared by Novosibirsk and Rostov-on-Don with an index of transport mobility of 0.60 . St. Petersburg $(0.54)$ ranked only $4^{\text {th }}$, despite its level of wealth and availability of a metro network. Next comes Ufa (0.52), Novgorod (0.51), Volgograd (0.50), Krasnoyarsk (0.48), Perm (0.48), Samara (0.47) and Voronezh (0.44).

The cities of Yekaterinburg (0.40), Chelyabinsk (0.39), Omsk (0.38) have very low transport mobility levels $(D)$; and Kazan with an index of transport mobility of 0.35 is at the bottom of the list, despite being second only to Moscow in terms of bus lanes (approximately $182 \mathrm{~km}$ ) and ongoing development of Kazan metro network. 
Table 5. Indices and levels of transport mobility of Russian super large and giant cities.

\begin{tabular}{|c|l|c|c|c|c|}
\hline Location & \multicolumn{1}{|c|}{ City } & $\begin{array}{c}\text { Area } \\
\left.\mathbf{( k m}^{2}\right)\end{array}$ & $\begin{array}{c}\text { Population } \\
\text { as of January 1, 2020 } \\
\text { (in thousands of } \\
\text { persons) }\end{array}$ & $\begin{array}{c}\text { Index of } \\
\text { transport } \\
\text { mobility } \\
\text { (ITM) }\end{array}$ & $\begin{array}{c}\text { Level of } \\
\text { transport } \\
\text { mobility } \\
\text { (LTM) }\end{array}$ \\
\hline 1 & Moscow & 2551.9 & 12678 & 0.81 & $\mathrm{~B}$ \\
\hline 2 & Saint-Petersburg & 1439.0 & 5398 & 0.54 & $\mathrm{D}$ \\
\hline 3 & Novosibirsk & 506.67 & 1625 & 0.60 & $\mathrm{D}$ \\
\hline 4 & Ekaterinburg & 468 & 1493 & 0.40 & $\mathrm{E}$ \\
\hline 5 & Kazan & 614.16 & 1257 & 0.35 & $\mathrm{E}$ \\
\hline 6 & Nizhny Novgorod & 466.5 & 1252 & 0.51 & $\mathrm{D}$ \\
\hline 7 & Chelyabinsk & 501.57 & 1196 & 0.39 & $\mathrm{E}$ \\
\hline 8 & Samara & 541.38 & 1156 & 0.47 & $\mathrm{D}$ \\
\hline 9 & Omsk & 566.9 & 1154 & 0.38 & $\mathrm{E}$ \\
\hline 10 & Rostov-on-Don & 348.5 & 1137 & 0.60 & $\mathrm{D}$ \\
\hline 11 & Ufa & 707.93 & 1128 & 0.52 & $\mathrm{D}$ \\
\hline 12 & Krasnoyarsk & 353.9 & 1093 & 0.48 & $\mathrm{D}$ \\
\hline 13 & Voronezh & 596.51 & 1058 & 0.44 & $\mathrm{D}$ \\
\hline 14 & Perm & 801.44 & 1055 & 0.48 & $\mathrm{D}$ \\
\hline 15 & Volgograd & 859.35 & 1008 & 0.50 & $\mathrm{D}$ \\
\hline
\end{tabular}

\section{Conclusions}

1. The recent research makes it possible to assess the level of transport mobility, while taking into account the structure of the transport systems of the largest and super-large cities.

2. The results of transport mobility levels obtained enable a comparative analysis to evaluate the performance of urban public transport systems and to identify long-term areas for growth.

3. A high level of transport mobility in a large city can be achieved without a welldeveloped tram network.

4. The large length of bus lanes is not indicative of a high level of transport mobility in large cities.

\section{References}

1. A.A. Dembich, Yu.A. Zakirova, M.S. Latypova. Kazan - resources and prospects of polycentric development, Izvestiya KGASU 3 (41), 57-66 (2017).

2. Zakirova Yu.A., Khusnutdinova S.R., Yurinova A.O. Formation of the functionalspatial model of the agglomeration belt in Kazan, Izvestiya KGASU 1 (35), 87-94 (2016).

3. K. Choi, R. Paterson. Examining interaction effects among land-use policies to reduce household vehicle travel: An exploratory analysis, Journal of Transport and Land Use 9 Iss. 4, 322-333 (2020). DOI: 10.1016/j.ijtst.2020.03.004.

4. F. Wolday, A. Tønnesen, P. Næss. Workplace location, polycentricism, and car commuting, Journal of Transport and Land Use 12 1, 785-810 (2019). DOI: 10.5198/jtlu.2019.1488.

5. R.B. Recio, I. Mateo-Babiano, S. Roitman. Mobility nodes and economic spaces: Links, tensions and planning implications, Journal of Transport and Land Use 12 1, 2019, 765-783. DOI: 10.5198/jtlu.2019.1478. 
6. R.H.M. Pereira, D. Banister, T. Schwanen, N. Wessel. Distributional effects of transport policies on inequalities in access to opportunities in Rio de Janeiro, Journal of Transport and Land Use 12 1, (2019). DOI: 10.2139/ssrn.3040844.

7. V.V. Silyanov. Ways to improve the efficiency of road traffic management in megacities, Science and Technology in the Road Sector 3, 1-4 (2013).

8. V.V. Zyryanov, R.R. Zagidullin. Methodology of estimation and choice of transport organization option at large-scale mass events, Intellect. Innovation. Investment $\mathbf{2}$, 43-47 (2017).

9. M.R. Yakimov. Concept of transport planning and traffic organization in large cities: Monography. Perm: Publishing house of Perm State Technical University, 175 (2011).

10. Y. Qiu, L. Zheng, Y. Du, S. Jiang. Performance evaluation of transit signal priorities on bus transit corridor based on data envelopment analysis, International Journal of Transportation Science and Technology, (2020). DOI: 10.1016/j.ijtst.2020.03.004.

11. Y. Tran, T. Yamamoto, H. Sato, T. Miwa, T. Morikawa. Attitude toward physical activity as a determinant of bus use intention: A case study in Asuke, Japan. IATSS Research, (2020). DOI: 10.1016/j.iatssr.2020.03.002.

12. P.-H. Hung, K. Doi, H. Inoi. User retention tendency of bus routes based on user behavior transition in an area with low mode share of public transport, IATSS Research 44 (2), (2020). DOI: 10.1016/j.iatssr.2019.09.001.

13. S. Moslem, Y. Çelikbilek. An integrated grey AHP-MOORA model for ameliorating public transport service quality, European Transport Research Review 12 (68), (2020). DOI: $10.1186 / \mathrm{s} 12544-020-00455-1$.

14. V.R. Vuchik. Transport in cities convenient for living: translated from English. Moscow: Territory of the Future, 576 (2011).

15. D. Esztergár-Kiss, T. Kerényi, T. Mátrai, A. Aba. Exploring the MaaS market with systematic analysis, European Transport Research Review 12 (1), (2020). DOI: 10.1186/s12544-020-00465-z.

16. L. Waldeck, J. Holloway, Q. van Heerden. Integrated land use and transportation modelling and planning: A South African journey, Journal of Transport and Land Use $\mathbf{1 3}$ (1), 227-254 (2020). DOI: 10.5198/jtlu.2020.1635.

17. M.-E. Will, Y. Cornet, T. Munshi. Measuring road space consumption by transport modes: Toward a standard spatial efficiency assessment method and an application to the development scenarios of Rajkot City, India, Journal of Transport and Land Use $\mathbf{1 3}$ (1), 651-669 (2020). DOI: 10.5198/jtlu.2020.1526.

18. John Holtzclaw. Using residential patterns and transit to decrease auto dependence and costs. - San Francisco, CA: Natural Resources Defense Council, 1994. June. Holtzclaw John. Convenient cities, Presentation at Green Fleets Project Workshop 3, (1995).

19. V.V. Shvetsov, V.V. Valdin et al. Rating of Russian cities by quality of public transport / Simetra. SPb., 91 (2020).

20. V.V. Silyanov. Transport flow theory in road design and traffic management. Moscow: Transport, 303 (1977).

21. A.N. Novikov, A.V. Kulev, M.V. Kulev, N.S. Kuleva. Methodology of organizing a route network of public urban passenger transport, The World of Transport and Technological Machines 48 Iss. 1, 85-92 (2015).

22. N.V. Yakunina, O.V. Kabanova, A.P. Fot. Analysis of passenger public carriages in foreign countries and contract transport policy in carriages, Transport of the Urals $\mathbf{3}$, 68-88 (2013).

23. N.V. Yakunina, N.N. Yakunin. Methodology to improve the quality of passenger transportation by road on regular routes: Monograph. Orenburg: Publishing and Printing Complex «Universitet» LLC, 289 (2013). 
24. R.R. Zagidullin. Features of traffic flows in cities under the conditions of large-scale sporting events, Science and Technology in the Road Sector 4, 4-6 (2015).

25. Ranking of Russia's bus lanes // Buslanes.ru: internet site. URL: http://www. buslanes.ru/ (access date: 10.10.2020).

26. Ranking of tram lanes in Russia // Tramlanes.ru: internet site. URL: http://www. tramlanes.ru / (access date: 10.10.2020).

27. V.N. Tregubov, L.V. Slavnetskova. Modelling of innovative processes in urban transport using system dynamics methods, Izvestiya Saratovskogo Universiteta 1, 29-37 2020. DOI: 10.18500/1994-2540-2020-20-1-29-37.

28. D. Levinson, H. Wu. Towards a general theory of access, Journal of Transport and Land Use 13 (1), 129-158 (2020). DOI: 10.5198/jtlu.2020.1660.

29. H. Zhang, K.N. Habib, J. Hawkins. A joint model of place of residence (POR) and place of work (POW): Making use of gibbs sampling technique to overcome arbitrary assumptions in contexts of data limitation, Journal of Transport and Land Use 12 (1), 873-892 (2019). DOI: 10.5198/jtlu.2019.1624.

30. B. Murphy, A. Owen. Temporal sampling and service frequency harmonics in transit accessibility evaluation, Journal of Transport and Land Use 12 1, 893-913 (2019). DOI: $10.5198 /$ jtlu.2019.1379.

31. L. Zheng, M. Oeser, B. van Wee. Combining accessibilities for different activity types: Methodology and case study, Journal of Transport and Land Use 12 1, 853-872 (2019). DOI: $10.5198 /$ jtlu.2019.1529. 